\title{
In Patients with Osteoarthritis and Rheumatoid Arthritis, Effects of Hand Physical Features on Hand Function
}

\author{
Osteoartrit ve Romatoid Artritli Hastalarda Elin Fiziksel Özelliklerinin El Fonksiyonu Üzerine \\ Etkilerinin Değerlendirilmesi
}

\section{Gulnihal Deniz', Ahmet Kavakli', Ozen Kan Sikoglu', Ahmet Zafer Perilioglu', Yıldız Ece², Murat Ogeturk', Furkan Bilek ${ }^{3}$}

${ }^{1}$ Department of Anatomy, Firat University Faculty of Medicine, Elazig; ${ }^{2}$ Department of Therapy and Rehabilitation, Sakarya University, Vocational School of Health Services, Sakarya; ${ }^{3}$ Department of Physiotherapy and Rehabilitation, Firat University Faculty of Health Sciences, Elazig, Turkey

\begin{abstract}
Aim: Osteoarthritis and Rheumatoid Arthritis, is one of the most common joint diseases in our country and in the world. Hand joint involvement and functions are of the most important factors that determine the impacts of the disease on daily activities. We aimed to determine the impact of the disease on the daily life activities by comparing hand grip strength and joint range of motion in healthy individuals and patients.
\end{abstract}

Material and Method: In this study, 166 female were included; 52 of which are healthy female, 62 of which are female patients with Rheumatoid Arthritis and 52 of which are female patients with Osteoarthritis. Grip and pinch strength were measured using the electronic hand and finger dynamometer. Standard and finger goniometer were used for range of motion measurement of wrist and fingers. Circumference and diameter of wrist and length of hand were measured with standard anthropometric measurement tools. Disability was scored by using health assessment questionnaire (HAQ).

Results: Hand and finger grip strength, range of motion measurement of wrist and fingers, and measurement of wrist circumference and diameter values of all patients and healthy groups were found statistically significant difference $(p<0.001)$. Hand length measurements of patients and healthy individuals there was no statistically significant difference ( $p>0.05)$. HAQ scores correlated negatively with grip and pinch strength were found in all individuals.

Conclusion: It was observed that the impairment of anatomical integrity, decreasing of grip and pinch strength, and pain affect independent daily life activities in the patients with Osteoarthritis and Rheumatoid Arthritis.

Key words: osteoarthritis; rheumatoid arthritis; grip strength; range of motion

\section{ÖZET}

Amaç: Osteoartrit (OA) dünyada ve ülkemizde en sık karșıssșlan eklem hastalığıdır. Romatoid artrit (RA) sinovyal enflamasyonla karakterize kronik, sistemik bir hastalıktır. OA ve RA'da el bileği ile el eklemleri ilk ve en sı etkilenen eklemlerdir. El eklemlerinin tutulumu, hastaların yașam kalitesinde belirgin bir azalmaya yol açar. Bu çalıșmada $R A$ ve $O A$ hastalarındaki el kavrama kuvveti ve eklem hareket açıklıklarının (EHA) sağlıkı bireylerle karșılaștırılması ve hastaların günlük yașam aktivitelerindeki bağımsızı̆̆ının değerlendirilmesi amaçlandı.

Materyal ve Metot: Çalıșmamızda Fırat Üniversitesi Hastanesi Fizik Tedavi ve Rehabilitasyon Polikliniğinde ve Romatoloji Polikliniğinde takip edilen, yașları 30 ile 60 arasında olan, Amerikan Romatoloji Birliği (ACR) kriterlerine göre RA tanısı konulmuș 62 kadın, 52 OA'lı kadın ve 52 sağlıkı kadın olmak üzere toplam 166 birey değerlendirmeye alındı. El kavrama kuvveti elektronik el dinamometresi, parmak kavrama kuvveti ise parmak dinamometresi ile ölçüldü. El bileği ve parmakların EHA ölçümleri için standart gonyometre ve parmak gonyometresi kullanıldı. El bileği çevresi ve çapı ile el uzunluk ölçümü standart antropometrik ölçüm aletleriyle gerçekleștirildi. Ayrıca çalıșmaya alınanların tamamına sağlık değerlendirme anketi (HAQ) uygulanarak özürlülük düzeyi belirlendi.

Bulgular: Tüm olgularda, el ve parmak kavrama kuvvetleri, el bileği ve parmakların EHA ölçümleri ile el bileği çevre ve çap değerleri arasında istatistiksel olarak anlamlı fark bulundu $(p<0,001)$. Hasta ve sağlıklı bireylerin el uzunluk ölçümünde istatistiksel olarak anlamlı bir fark bulunmadı ( $p>0,05)$. Tüm olgularda, HAQ skoru ile el ve parmak kavrama kuvveti arasında negatif yönde çok güçlü korelasyon bulundu.

Sonuç: $O A^{\prime} l ı$ ve RA'lı hastalarda anatomik bütünlügün bozulmaSI, EHA'nın, el ve parmak kavrama kuvvetlerinin azalması ve ağrı, hastaların günlük yașam aktivitelerindeki bağımsızlığını etkilemiștir.

Anahtar kelimeler: osteoartrit; romatoid artrit; kavrama kuvveti; hareket açıkığı

IIetișim/Contact: Furkan Bilek, Furat University Faculty of Health Sciences, Department of Physiotherapy and Rehabilitation, Elazig, Turkey • Tel:054427722 49 • E-mail:fzt.furkanbilek@gmail.com • Geliș/Received:02.04.2020 • Kabul/Accepted:05.10.2020

ORCID: Gülnihal Deniz, 0000-0002-5944-8841 • Ahmet Kavakl, 0000-0003-3410-912X • Özen Kan Şıkoğlu, 0000-0002-4356-9577 Ahmet Zafer Perilioğlu, 0000-0002-6336-3568 • Yuldiz Ece, 0000-0003-0825-0250 • Murat Ögetürk, 0000-0002-5744-4812 • Furkan Bilek, 0000-0003-1567-7201 


\section{Introduction}

The hand is the most developed part of the human body which can make special movements, and which is one of its crucial components which influence the functionality of upper limbs. A motor and functional unit of the body is at the same time the main organ of the sense of touch. The genes of the individual and the genetic take part in the shaping development, and differentiation of the hand. While the hands consist of bones, cartilage, and muscular tissues in the development process, the external factors and facilities affect the structure of the hand ${ }^{1}$. One of the hand functions is grip strength, which is widely used for indicating the severity of rheumatic diseases, and its prognosis ${ }^{2}$. In this study, different from other studies in the literature, we investigated the effects of hand functions and physical properties on health status in both rheumatoid arthritis (RA) and Osteoarthritis (OA) patients.

$\mathrm{OA}$ is a rheumatic disease which is more endemic in elders, and it's a generative arthropathy characterized with erosion in the articular cartilage, osteophyte, subchondral sclerosis, synovial membranes on the joint margin and biochemical and morphologic changes in the joint capsule. Hand osteoarthritis is the most frequent type of general OA. It is more endemic among 45 + women than among men $^{3}$. Though RA is characterized with inflammation and proliferation of the synovial membrane tissue at the joints and tendon sheaths, and sometimes it's an autoimmune disease which performs multisystem involvement, and its etiology is unknown. RA makes its most typical variations on the hands. The first damage of the hands comes generally through tenosynovitis as storiform distensions in the middle joints of the fingers or generalized swelling on the dorsum of the hand ${ }^{4}$.

As mentioned before, hand joints are the joints which are frequently held by $\mathrm{OA}$ and $\mathrm{RA}$, and these are the crucial factors which determine hand involvement, the functioning of the hand, and the daily life activities. Gripping is a functioning of the hand which is important for the continuity of daily life activities. The prehensile force is because of this reason accepted as an objective measure in upper extremity performance assessments ${ }^{5,6}$. The purpose of our research is to assess the independence of patients in their daily life activities by comparing the results of the measured range of motion and prehensile forces in the wrist joints of patients with OA and patients with RA, with the results obtained from healthy individuals, and aiding clinicians in taking the required precautions by closely following loss of functions, after having indicated the available failures.

\section{Material and Method}

Our research was materialized by concentrating on 62 women with RA, 52 women with OA who were kept track of at the Physiotherapy Rehabilitation and Rheumatology Policlinics and who got diagnosis in accordance with the criteria of American College of Rheumatology, and 52 healthy women (within the age range of 30-60). The most important reason of preferring women is that the prevalence of RA is threefold in comparison to men, and hand osteoarthritis is more endemic by women ${ }^{7,8}$.

All the individuals who joined our research, gained written and verbal information about the research and it was ensured that they joined voluntarily. Individuals who have hand joints, wrist joints and/or finger joints fracture history, who have suffered diseases which left them neurologic sequelae, individuals with systemic diseases, members of an occupational group who continuously work with their hands were excluded from this research. The demographic features of all the subjects who joined our research were recorded.

The body mass index (BMI) and the health assessment questionnaire (HAQ) scala were measured in all individuals. Pain was assessed on the visual analog scale (VAS), which is, in fact, a horizontal $100 \mathrm{~mm}$ line with the far left end representing "no pain" and the far right end representing "the worst possible pain" on which the patient marks their intensity of pain ${ }^{9-13}$.

Hand and Finger Grip Strength Measurements: All the measurements were materialized on the dominant and non-dominant hand. No significant difference was found between the dominant and non-dominant hand in the statistical examination, and their averages were taken into account because of this reason. The electronic hand dynamometer [Electronic Hand Dynamometer (HS-005), China] was used for handgrip strength assessment, and the finger grip strength was assessed in "kg" unit with the manual pinchmeter (Sammons Preston, Inc. Bolingbrook, IL 60440-4989).

The standard test positions of the American Society of Hand Therapists were used in assessing grip and grasp strength. Handgrip strength measures; these were measured while the patient was in the sitting position, arm in adduction, forearm $90^{\circ}$ in flexion and in the neutral 
position, hand wrist $0^{\circ}-30^{\circ}$ extension and $0^{\circ}-15^{\circ}$ ulnar abduction position. The patients were demanded to grip voluntary to the utmost ${ }^{1,14-16}$.

The patients were in the sitting position, arm in adduction and forearm $90^{\circ}$ in flexion and in the neutral position for measuring the finger grip strength. The patient had to hold the top side of the pinch meter with the tip of his thumb, and the underside with the radial side of his forefinger and push on the pinch meter in force ${ }^{14-16}$.

Interval was taken between each measurement within the test process of the handgrip and finger grip strength, to do 3 measurements and record the averages ${ }^{17,18}$.

Hand and Finger Anthropometrics: All the measurements were carried out on both left and rights hands, and the average was calculated. An inelastic, foldable measuring tape with a width of $7 \mathrm{~mm}$ was used for measuring all the length and perimeter measuring. A medical caliper was used for measuring diameters. A plastic goniometer (Sammons Preston, USA) was used for the range of motion of the hand joint, and a metal finger goniometer was used for the range of motions of the finger joint ${ }^{19}$.

\section{Statistical Analysis}

As a result of the sample taken from the current literature and the power analysis, it was calculated that when 96 cases were taken into the study, $90 \%$ power would be reached with $95 \%$ confidence ${ }^{11}$. The statistical analysis was materialized by using SPSS 16.0. The statistical analysis of all the individuals were carried out on dominant and non-dominant hands. Multi-varied variance analysis and correlation analysis were used in our research for the measure analysis of handgrip strength, finger grip strength, the range of motion of joints. The arithmetic averages $(\mathrm{X})$ of all the data of the individuals, and standard error (SE) values were calculated. The level of statistical significance was considered at $\mathrm{p}<0.05^{20}$.

\section{Results}

166 women in total, which consisted of 52 women with OA (31.3\%), 62 women with RA (37.3\%), and 52 healthy women $(31.3 \%)$ were put into perspective in our research which was planned with the purpose to compare the range of motion, and grip strength in the hand joints of OA and RA patients with healthy individuals. The age range of the individuals who were accepted to the research was 30-60 years, and their average of age was $46.86 \pm 0.86$.
A statistically advanced level of significant difference was found between all groups (control, OA and RA) in terms of disease duration, pain level and HAQ scores $(p<0.001$, Table 1$)$. A statistically advanced level of significant difference was found in the duration of disease, pain level, swollen joint, sensitive joint, and HAQ scores between the control group and OA patients, and the control group and RA patients $(\mathrm{p}<0.001$, Table 1$)$. While a statistically advanced level of significant difference was found in the duration of disease, pain level, and HAQ scores between OA patients, and RA patients $(p<0.001)$, a less significant difference was found in swollen joints $(p<0.05)$. No statistically significant difference was found in sensitive joints between OA patients and RA patients ( $p>0.05$, Table 1$)$.

A statistically advanced level of significant difference was found in the circumference and diameter of the hand wrist between the control group and OA patients, and the control group and RA patients $(\mathrm{p}<0.001)$, but there was no statistical difference between hand length measures $(p>0.05)$. While there was a significant difference the hand wrist diameter measures between OA patients and RA patients $(\mathrm{p}<0.05)$, the differences in the hand wrist circumference and the hand length measure were insignificant $(p>0.05)$. A statistically advanced level of significant difference was found in the hand wrist flexion, extension, ulnar abduction, radial abduction between the control group and OA patients, and the control group and RA patients, as well as in OA and RA patients $(\mathrm{p}<0.001$, Table 2$)$.

A statistically advanced level of significant difference was found in the range of motion of all the finger joints between the control group and OA patients, and the control group and RA patients $(\mathrm{p}<0.001)$. In the examination between OA patients and RA patients; while a statistically advanced level of significant difference was found in I. carpometacarpal joint abduction, flexion, I. metacarpophalangeal joint flexion, I. interphalangeal joint flexion, II- V. metacarpophalangeal joint flexion, abduction, II- V. distal interphalangeal joint flexion, II- V. proximal interphalangeal joint flexion $(p<0.05)$, no statistically significant difference was found in I. carpometacarpal joint extension, and II-V. metacarpophalangeal joint extension ( $\mathrm{p}>0.05)$.

Handgrip strength; $27.2 \pm 0.5$ in control groups, $12.2 \pm 0.4$ in $\mathrm{OA}$ patients, $5.5 \pm 0.3$ in RA patients. Finger grip strength; $7.6 \pm 0.2$ in control groups, $4.6 \pm 0.1$ in OA patients, 3.5 \pm 0.1 in RA patients (Figure 1). A statistically advanced level of significant 
Table 1. Comparison of disease duration, pain intensity, sensitive joints, swollen joints and $H A Q$ scores in all cases

\begin{tabular}{lccccc}
\hline & Disease duration & Pain intensity & Sensitive joints & Swollen joints & HAQ scores \\
\hline OA & $6.3 \pm 0.38$ & $1.4 \pm 0.14$ & $4.6 \pm 0.36$ & $3.9 \pm 0.33$ & $2.1 \pm 0.05$ \\
RA & $8.6 \pm 0.60$ & $3.18 \pm 0.23$ & $5.3 \pm 0.32$ & $4.8 \pm 0.30$ & $2.92 \pm 0.02$ \\
Control group & $0 \pm 0$ & $0.06 \pm 0.02$ & $0 \pm 0$ & $0.02 \pm 0.02$ & $0.1 \pm 0.03$ \\
Control - OA * & 0.001 & 0.001 & 0.001 & 0.001 & 0.001 \\
Control - RA * & 0.001 & 0.001 & 0.001 & 0.001 & 0.001 \\
OA - RA * & 0.001 & 0.001 & $\mathbf{0 . 1 7}$ & $\mathbf{0 . 0 4}$ & 0.001 \\
\hline
\end{tabular}

HAQ, Health Assessment Questionnaire; OA, 0steoarthritis; RA, Rheumatoid Arthritis; ${ }^{*} \mathrm{p}$ : the difference between all groups (control, OA patients and RA patients)

Table 2. Comparison of hand wrist circumference and diameter measurement, hand length measurement, hand wrist flexion, extension, ulnar abduction, and radial abduction in all cases

\begin{tabular}{|c|c|c|c|c|c|c|c|}
\hline & $\begin{array}{c}\text { Hand wrist } \\
\text { circumference }\end{array}$ & $\begin{array}{l}\text { Hand wrist } \\
\text { diameter }\end{array}$ & $\begin{array}{l}\text { Hand } \\
\text { length }\end{array}$ & $\begin{array}{l}\text { Hand wrist } \\
\text { flexion }\end{array}$ & $\begin{array}{l}\text { Hand wrist } \\
\text { extension }\end{array}$ & $\begin{array}{c}\text { Hand wrist } \\
\text { ulnar abduction }\end{array}$ & $\begin{array}{c}\text { Hand wrist } \\
\text { radial abduction }\end{array}$ \\
\hline $\mathrm{OA}$ & $16.4 \pm 0.1$ & $5.3 \pm 0.4$ & $18.1 \pm 0.1$ & $32.6 \pm 1.1$ & $35 \pm 1.1$ & $13.1 \pm 0.3$ & $10.5 \pm 0.2$ \\
\hline RA & $16.6 \pm 0.8$ & $5.5 \pm 0.4$ & $17.9 \pm 0.1$ & $27.1 \pm 0.9$ & $27.2 \pm 0.9$ & $10.5 \pm 0.3$ & $8.9 \pm 0.3$ \\
\hline Control Group & $15.8 \pm 0.1$ & $5.1 \pm 0.04$ & $18.03 \pm 0.08$ & $72.8 \pm 0.6$ & $69.7 \pm 0.4$ & $25.4 \pm 0.4$ & $19.1 \pm 0.3$ \\
\hline Control $-0 A^{*}$ & 0.001 & 0.001 & 0.940 & 0.001 & 0.001 & 0.001 & 0.001 \\
\hline Control - RA * & 0.001 & 0.001 & 0.902 & 0.001 & 0.001 & 0.001 & 0.001 \\
\hline$O A-R A$ * & 0.14 & 0.016 & 0.713 & 0.001 & 0.001 & 0.001 & 0.001 \\
\hline
\end{tabular}

OA, Osteoarthritis; RA, Rheumatoid Arthritis; ${ }^{\mathrm{p}} \mathrm{p}$ : the difference between all groups (control, OA patients and RA patients)

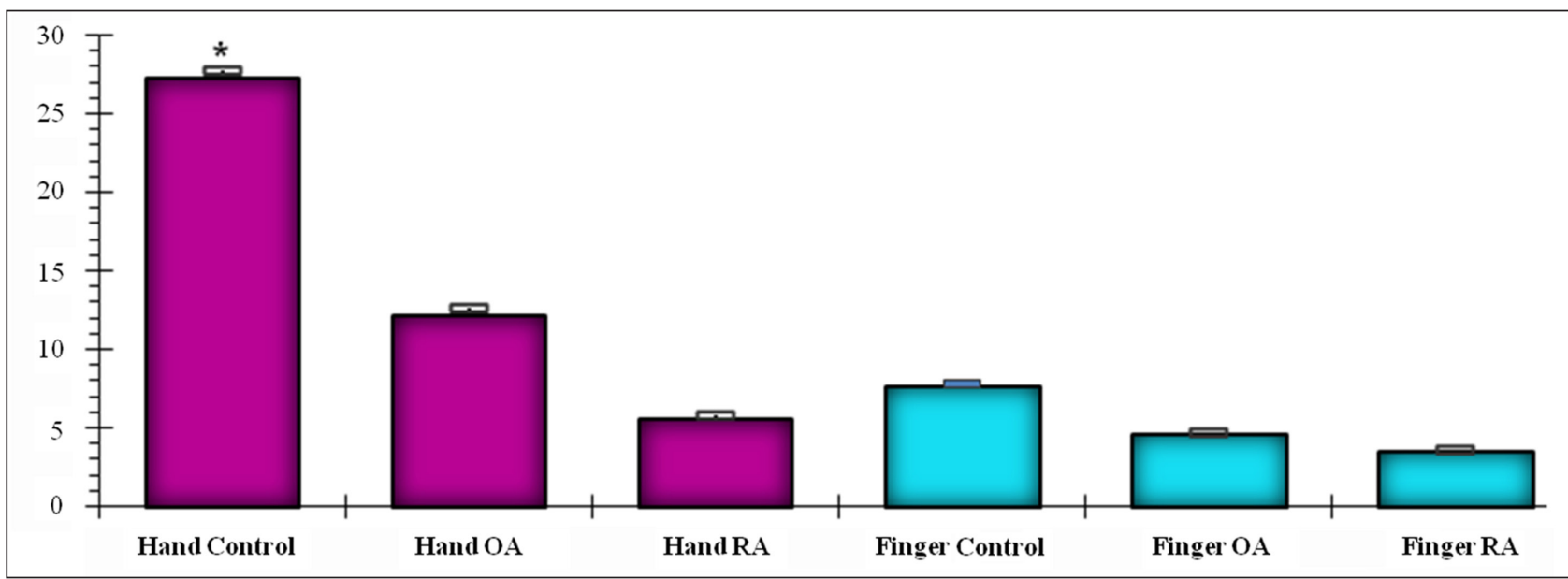

Figure 1. Hand and finger grip strength values in patients with $R A$ and $O A$, the control group ${ }^{*} p=0.001$ (OA, Osteoarthritis; RA, Rheumatoid Arthritis; * ${ }^{*}$ : the difference between all groups [control, OA patients and RA patients]).

difference in the hand and finger grip strength was found in the hand and finger grip strength between the control group and OA patients, and the control group and RA patients, and between OA patients and RA patients $(\mathrm{p}<0.001)$.

\section{Discussion}

Evaluation of handgrip strength in measurements materialized with the purpose to review upper extremity functions is an important measure which is quite often applied $^{21,22}$. Handgrip strengths are measured as an indicator of the severity of the upper extremity strength and disease activity, in researches conducted on OA patients and RA patients ${ }^{23}$. Balogun \& Akinloye, report that the grip strength is the indicator of the upper extremity functional continuity, and that it's also used for indicating the severity of the disease caused by upper extremity traumatisations ${ }^{24}$. 
Ozkan, et al. ${ }^{25}$ reported that they've observed sensitive joints in $45 \%$ of the patient population and in $35 \%$ of the control group, Bagis, et al. ${ }^{26}$ reported that they've observed sensitive joints in $57 \%$ of the patient population, and Kose, et al. ${ }^{27}$ reported that they've observed swollen-sensitive joints in RA patients were abundant when compared with swollen-sensitive joints in OA patients in accordance with the literature. While the number of swollen-sensitive joints of all the individuals was found of statistically advanced level in our research, no statistically significant difference was found in the number of sensitive joints of OA and RA patients $(p>0.05)$. The reason of this, is that it was considered that the sensitive joint structures caused by degeneration and deformities, which occur in the joints by both diseases-, could be equal. The number of swollen joints between OA patients and RA patients was statistically found significant $(\mathrm{p}<0.05)$.

It's reported that pain is an important clinical finding in accordance with many researches materialized on OA patients and RA patients. Pollard, et al. ${ }^{28}$ reported that pain and handicap levels have an influence on the psychological situation and the general well- being of the patient, Hagen et al. ${ }^{29}$ reported that the main complaints of RA patients was the pain they suffered, Altindag et al. ${ }^{30}$ reported that the pain level of RA patients was higher than the pain level of OA patients. Similar to the researches indicated in the literature, the pain level of RA patients in our research was reported to be higher than the pain level of OA patients. However, the pain levels of the OA patients and the RA patients indicated in our research were found to be low in comparison with the researches in the literature. It's considered that it may arise from the analgesic consumption of patients.

The general disability assessment of daily life activities is carried out with HAQ in many researches in the literature $^{16,31}$. It's indicated in many researches on OA patients and RA patients that the HAQ score is correlated with painful, swollen and sensitive joints reflected by disease activities; it's indicated that the general disability measurement was carried out with HAQ score, that the disease process was correlated to painful, swollen and sensitive joints ${ }^{11}$. Stamm et al. ${ }^{31}$ and Ekimler Suslu ${ }^{16}$ reported these in their researches about hand OA; they reported that the HAQ average score of OA patients was statistically significant and higher in comparison with the control group. The HAQ scores of all the individuals in our research also were reported as statically significant on advanced level. A positive, linear relation was found with HAQ scores between duration of disease, pain level, the number of swollen joints and the number of sensitive joints in our study.

Researches related with the length, circumference and diameter of the hand are moreover examined in the literature on healthy individuals ${ }^{32,33}$. Similarly to the researches in the literature, it was reported in our research that the length of the hands of OA patients was $18.1 \pm 0.1 \mathrm{~cm}$, the length of the hands of RA patients was $17.9 \pm 0.1 \mathrm{~cm}$, the length of the hands of the control group was $18.03 \pm 0.08 \mathrm{~cm}$. No statistically significant difference was found in the hand length measurement of all the individuals. The measurements of RA patients in wrist circumference and diameter measures, was much more in comparison with $\mathrm{OA}$ patients and the control group. It was considered that this caused by oedema, inflammation, and swollen joints. It was considered that, similar deformation and oedema occurring on OA patients and RA patients caused the absence of statistically significant differences between the wrist circumference of OA patients and RA patients.

The grip tests are frequently applied in clinics for reviewing diseases which have influence on muscle strength, and determining the functionality of the hand, it's an easy to use and practical method. One of these disease groups is the rheumatic disease ${ }^{34}$. Ekblom et al. ${ }^{35}$ reported that the muscle strength of RA patients is $33 \%-52 \%$ lower in comparison to healthy individuals, and this has a crucial effect on the functionality tests. Wolfe et al. ${ }^{36}$ have exposed that grip strength is an important disability indicator in RA patients. Ekimler Suslu ${ }^{16}$ reported in his research that he'd discovered that the grip strength of OA patients was significantly lower in comparison to healthy individuals. Jones et al. ${ }^{37}$ and Kurtaran et al. ${ }^{38}$ found that the grip strength of patients with hand OA was lower in comparison to the control group. Kose et al. ${ }^{27}$ has found hand grip strength at most in healthy individuals, and at least in RA patients. No statistically significant difference was found in the handgrip strength measures, measured among OA patients and healthy individuals in Kose et al.'s study ${ }^{27}$. Minor et al. ${ }^{23}$ found statistically significant difference among RA and OA patients, and detected that the grip strength of RA patients was quite low in comparison to OA patients. In our research; it was detected that the grip strength of OA patients and RA patients was statistical significant of advanced level when compared with healthy individuals, and with each other $(p<0.001)$. 
The finger grip strength (lateral grip), is the strongest grip in comparison to other finger grips. Strength of ca. $4 \mathrm{~kg}$. is enough for performing $90 \%$ of daily life activities. Most of simple activities can be performed with grasp strength of ca. $1 \mathrm{~kg}$. Ekimler Suslu ${ }^{16}$ reported in his research that; the finger grip strength of OA patients was significantly lowered compared to healthy individuals. Tastekin et al. ${ }^{11}$ reported that the finger grip strength of RA patients was $5.40 \pm 1.9 \mathrm{~kg}$. Ozeri et $a .^{39}$ and Kurtaran et al. ${ }^{38}$ reported that the finger grip strength of RA patients was lowered. The finger grip strength of OA patients was $4.6 \pm 0.1$, the finger grip strength of RA patients was $3.5 \pm 0.1$ and the finger grip strength of the control group was $7.6 \pm 0.2 \mathrm{~kg}$ in our research. It was detected that the grip strength among the control group and OA patients, and the control group and RA patients, and OA patients and RA patients was statistical significant of advanced level in our study $(\mathrm{p}<0.001)$.

It's emphasized that in the literature basic anthropometric measures will be useful in indicating hand grip strength in RA patients, that at the same time knowing the grip strength in these patients is important in indicating the level of functional loss ${ }^{40}$. According to the literature the grip strength has increased, while the wrist diameter, circumference and the length of the hand increase in the correlation analysis materialized between the handgrip strength of healthy individuals and the wrist circumference, the wrist diameter, and the length of the hand were measured ${ }^{1,40}$. It was considered that the reason of the negative correlation in our research is that, there was oedema, inflammation, and a swollen joint structure in the wrist area of RA patients and $\mathrm{OA}$ patients.

Independent living can be provided with locomotor skills and tenacity of physical strength. There are many health status indicators in which the individual's functional capacity can be reviewed. The HAQ score which is used in reviewing daily life activities reflects the activity of the disease, and it's exposed in many researches that it's related with painful, swollen, sensitive joints ${ }^{11,25}$. It's reported in previous researches about RA patients and OA patients that in progress of time patients undergo a progressive reduction in their grip strength. Attentive to this fact, a significantly negative correlation was detected in the relation between the muscle strength and $\mathrm{HAQ}^{11}$. It was indicated that the handgrip strength of patients whose HAQ score was high, came out to be low but that this fact wasn't statistically significant anyway, and a significantly negative correlation was detected between the HAQ score and the lateral grasp strengths, in a research of Ekimler Suslu ${ }^{16}$. A significantly negative correlation was reported in our research between the handgrip strength and HAQ scores $(r=-0.901, p<0.001)$. Another significantly negative correlation was reported between the finger grip strength and HAQ scores in our research $(\mathrm{r}=-0.781, \mathrm{p}<0.001)$.

Callahan et al. ${ }^{41}$ indicated that in a research on RA patients the range of motion of the joints was affected negatively in a process of five years ${ }^{41}$. Active range of motion of the joint; effected by situations like the collapse of the joint integrity like, reduced muscle strength together with deformities, and joint spacing stenosis. The collapse of the anatomical integrity, range of motion restrictions, muscle strength losses, probable sensory problems, and pain may also affect the hand usage skills in RA. Range of motion restrictions caused by deformities and joint damages; cause disruption in hand functionality of patients and are accompanied by difficulties in daily life activities ${ }^{11}$. Motion restriction caused by decrease of range of motion of the joints in OA patients; causes function loss and reduction of grip strength ${ }^{42,43}$. Ozeri et al. ${ }^{39}$ have found that as a result of a decrease in the range of motion of the joint a motion restriction was obtained in a research on RA patients, and that this was related with a decrease of the grip strength. No literature was found with a related research which profoundly indicates the range of motion of the joints in hands and fingers of OA patients and RA patients, as it is in this research. Researches were rather made on the anthropometric measures, the length of the fingers and hands, the circumference and diameter in OA patients and RA patients. The range of motion of wrist joints measures and the range of motion of finger joints measures of OA patients, RA patients, and healthy individuals were examined in our research. Statistically significant differences of advanced level were found in the range of motion of the joints measures between all groups in this study.

The rapid increase of joint deformities, decrease of the range of motion of the joints, many sensitive-swollen joints, and a high pain level in RA patients causes disruption of hand functionality of the patients and difficulties in daily life activities. In our research, all the grip strength and range of motion of the joints measures of RA patients were quite low when compared to OA patients and healthy individuals. In all the researches on RA patients and OA patients indicated in the literature, statistically significant differences were 
reported $^{23,27}$. Conclusion; the disease activity of RA patients affects the range of motion of joints and the grip strength. As a matter of fact, daily life hand functionalities are related with disability levels measured with $\mathrm{HAQ}$, grip strengths, and the range of motion of joints.

\section{Acknowledgements}

We would like to thank all the patients and the colleagues at the hospital for their cooperation.

\section{Financial Disclosure and Conflict of Interest}

We affirm that we have no financial affiliation (including research funding) or involvement with any commercial organization that has a direct financial interest in any matter included in this manuscript.

\section{Compliance with Ethical Standards}

Ethical approval our study was approved according to the local ethical committee. All patients gave informed written consent to be enrolled into the study according to the Declaration of Helsinki.

\section{References}

1. Demirel P. Comparison of Hand Anthropometric Measurements and Grip Strength in Different Sports Branches: Master of Science Thesis. Zonguldak: Karaelmas University, Institute of Health Sciences Deparmant of Anatomy, 2005.

2. Nordenskiold U, Grimby G. Assesment of disability in women with rheumatoid arthritis in relation to grip force and pain. Disabil Rehabil 1997;19(1):13-9.

3. Di Cesare PE, Abramson SB. Pathogenesis of osteoarthritis. In: Harris ED, Budd RC, Firstein GS, Genovese MC, Sergent JS, Ruddy S, et al, ed. Kelly's Textbook of Rheumatology 7th edition. Philedelphia. Saundersp 1493-513, 2005.

4. Haris ER Jr. Rheumatoid Arthritis: pathophysilogy and implications for therapy. N Egly J Med 1990;322:1277-89.

5. Grabiner MD, Rasch PJ. Kinesiology and Applied Anatomy. Philadelphia: Lea and Febiger p.151-68, 1989.

6. İnce Parpucu T. To Research Reliability and Validity Hand Held Dynamometer In Assesment For Wrist Muscle Strength In Healthy Young İndividuals: Master Of Science Thesis, Isparta: Süleyman Demirel Üniversity, Institute of Health Sciences Deparmant of Anatomy, 2009.

7. Karaaslan Y. Osteoartrit. Ankara: MD., 2000.

8. Lipsky PE. Rheumatoid Arthritis. In: Kasper DL, Braunwald E, Fauci AS, Hauser SL, Longo DL, Jameson JL (Editors). Harrıson's Principles of Internal Medicine. New York: McGrawHill p.1968-77, 2005.
9. Fries JF, Spitz P, Krainez RG, Holman HR. Measurement of patient outcome in arthritis. Arthritis Rheum 1980;23:137-45.

10. Kucukdeveci A, Sahin H, Ataman S, Griffiths B, Tennant A. Issue in cross-cultural validity: example from the adaptation, reliability, and validity testing of a Turkish version of the Stanford Health Assessment Questionnaire. Arthritis \& Rheum 2004;51:14-9.

11. Tastekin N, Uzunca K, Birtane M, Demirbağ Kabayel D, Öztürk G. The Relationship of Range of Motion and Grip Strength of the Hand with Disease Activity, Hand Functions and Disability in Patients with Rheumatoid Arthritis. Romatizma 2006;21:13-7.

12. Bolukbasi N. Osteoartritin Klinik Değerlendirmesinde Kullanılan Ölçütler. Turkiye Klinikleri Journal of Physical Medicine Rehabilitation 2002;2(3), 171-176. (Turkish)

13. Kilincer C, Zileli M. Görsel analog hasta tatmini skalası. Balkan Medical Journal 2006;3:113-8. (Turkish)

14. Mathiowetz V, Kashman N, Volland G, Weber K, Dowe M, Rogers S. Grip And Pinch Strength: Normative Data For Adults. Arch Phys Med Rehabil 1985;66(2):69-74.

15. Evcik D, Kizilay B. Correlation Of Hand Grip Strength And Disability In Daily Living Activities In Geriatric Patients. Turkish Journal of Geriatrics 2001;4:11-4.

16. Ekimler Süslü F. The Effects of Hand Osteoarthritis on Hand Strength, Hand Functions, Manuel Dexterity and Daily Activities of Life in Post-menopausal Women: Expertise thesis, Isparta: Süleyman Demirel Üniversity, Department of Physical Medicine and Rehabilitation, 2008.

17. Haidar SG, Kumar D, Bassi RS, Deshmukh SC. Average versus maximum grip strength: Which is more consistent? J Hand Surg[Br] 2004;29:82-4.

18. Halpern CA, Fernandez JE. The effect of wrist and arm postures on peak pinch strength. J Hum Ergol 1996;25:115-30.

19. Otman SA, Demirel H, Sade A. Tedavi hareketlerinde temel değerlendirme prensipleri 2. baskı, Ankara, Sinem 1998. (Turkish)

20. Alpar R. Spor Bilimlerinde Uygulamalı İstatistik 2. Basım, Ankara: Nobel Yayın, 2001. (Turkish)

21. Nicolay CW, Walker AL. Grip strength and endurance: Influences of anthropometric variation, hand dominance and gender. Int J Ind Ergon 2005;35:605-18.

22. Gabriel YF Ng, Andy CCF. Does elbow position affect strength and reproducibility of power grip measurements? Physiotherapy 2001;87:68-72.

23. Minor MA, Hewett JE, Webel RR, Dreisinger TE, Kay DR. Exercise tolerance and disease related measures in patients with rheumatoid arthritis and osteoarthritis. J Rheumatol 1988;15:905-11.

24. Balogun JA, Akinloye SA. Grip strength as a function of age, height, body weight and quetelet index. Physiotherapy Theory and Practice 1991;7:111-9.

25. Ozkan B, Keskin D, Bodur H, Barca N. The effect of radiological hand osteoarthritis on hand function. Clin Rheumatol 2007;26(10):1621-5. 
26. Bagis S, Sahin G, Yapici Y, Cimen OB, Erdogan C. The effect of hand osteoarthritis on grip and pinch strength and hand function in postmenopausal women. Clin Rheumatol 2003;22(6):420-4.

27. Köse N, Arıkan H, Çalgüneri M. Comparision of hand grip strength and assesment methods in osteoarthritis, rheumatoid arthritis and healty individuals. Fizyoterapi ve Rehabilitasyon 2000;11(3):110-8.

28. Pollard L, Choy EH, Scott DL. The consequences of rheumatoid arthritis: Quality of life measures in the individual patient. Clin Exp Rheumatol 2005;23(Suppl 39):43-52.

29. Hagen KB, Kvien TK, Bjorndal A. Musculoskeletal pain and quality of life in patients with noninflammatory joint pain compared to rheumatoid arthritis: a population survey. J Rheumatol 1997;24:1703-9.

30. Altindag Ö, Altindag A, Soran N, Tabur H. Depression and disability in patients with rheumatoid arthritis and osteoarthritis. Bulletin of Clinical Psychopharmacology 2007;Vol:17, N:1.

31. Stamm T, Mathis M, Aletaha D, Kloppenburg M, Machold K, Smolen J. Mapping hand functioning in hand osteoarthritis: comparing self-report instruments with a comprehensive hand function test. Arthritis Rheum 2007;57(7):1230-7.

32. Kulaksiz G, Gozil R. The Effect of hand preference on hand anthropometric measurements in healthy individuals. Annals of Anatomy 2002;184:257-65.

33. Chuang MC, You M, Cai D, Chen CC. Isometric Muscle Strength of Chinese Young Males In Taiwan. Ergonomics 1997;40(5):576-90.

34. Nordenskiold U, Grimby G. Assesment of disability in women with rheumatoid arthritis in relation to grip force and pain. Disabil Rehabil 1997;19(1):13-9.
35. Ekblom B, Lövgren O, Alderin M, Fridström M, Sätterström G. Physical performance in patients with rheumatid arthritis Scand J Rheumatol 1974;3:121-5.

36. Wolfe F, Cathey MA. The assessment and prediction of functional disability in rheumatoid arthritis. J Rheumatol 1991;18:1298-306.

37. Jones G, Cooley HM, Bellomy N. A cross sectional study of the association between Haberdan's nodes, radiographic osteorathritis of the hands, grip strenght, disability and pain. Osteoarthritis Cartilage 2001;9:606-11.

38. Kurtaran A, Sulubulut N, Selcuk B, Akyuz M. Effect of Osteoartritis on Hand Functions. Fiziksel Tip Dergisi 2003;6(3):7-10.

39. Cimen BO, Bagis S, Sahin G, Bicer A, Yapici Y, Kanik A, et al. Relationship between hand osteoarthritis and benign joint hypermobility. Romatizma 2003;18(1):27-31.

40. Fraser A, Vallow J, Preston A, Cooper RG. Predicting normal grip strength for reumatoid arthritis patients. Rheumatol (Oxford) 1999;38:521-8.

41. Callahan LF, Pincus T, Huston JW, Brooks RH, Nance EP Jr, Kaye JJ. Measures of activityand damage in rheumatoid arthritis: depiction of changes and prediction of mortality over five years. Arthritis Care Res 1997;10:381-94.

42. Saridogan M. Clinical Findings of Osteoarthritis According to the Joints. Turkish Journal of Geriatrics Supplement 2011;14(1):31-6.

43. Dincer F, Ozdemir O, Samut G. Diagnosis and Treatment of Hand Osteoarthritis. J PMR Sci 2011;14 Suppl:12-8. 